\title{
EFFECT OF GAMMA IRRADIATION ON CERTAIN BIOLOGICAL ASPECTS OF THE BLACK CUTWORM, Agrotis ipsilon ( HUFN.) \\ EIShabrawy, H. A. ${ }^{1}$; W. A. Abd Elhamid ${ }^{2}$; S. M. Ebrahim ${ }^{2}$ and M. M. Elbolok ${ }^{1}$ \\ 1 Department of Economic Entomology and Pesticides, Faculty of Agriculture, Cairo University, Giza, Egypt. \\ 2 Biological Applications Department, Neuclear Research Center, Atomic Energy Authority, Egypt.
}

\begin{abstract}
The biological effects of low doses of gamma radiation on full grown male and female pupae of the black cut worm, Agrotis ipsilon (Hufn.) concerning their $\left(\mathrm{P}_{1}\right)$ generation and its influence on their first $\left(\mathrm{F}_{1}\right)$ generation were studied.

The results confirmed that, the average number of eggs of the parental generation $\left(P_{1}\right)$ was significantly reduced when both sexes were exposed to 100 and 150 Gy. The highest reduction was clearly observed in $P_{1}$ female. However, on exposing both sexes to $50 \mathrm{~Gy}$, results showed that, the average number of eggs was not significantly affected in case of full grown male pupae, while it was significantly reduced in case of irradiated full grown female pupae in comparison to the untreated control.

Results also showed that the percentage of egg hatch of $P_{1}$ generation was gradually reduced by increasing the irradiation dose in both the full grown male and female pupae. This reduction was significant at 50 , 100 and 150 Gy in case of $P_{1}$ female generation and at 100 and 150 Gy in case of $P_{1}$ male generation in comparison to the untreated control as the percentage of egg hatch was not significantly reduced at 50 Gy for $\mathrm{P}_{1}$ male. The results on mating ability through the $\mathrm{P}_{1}$ generation showed that irradiation of males and females by low doses of gamma rays at 50 and 100 Gy did not clearly affect the percentage of mating at any of the tested doses.

While the percentage of mating clearly reduced at $150 \mathrm{~Gy}$ in both sexes. Results also showed that, the average number of spermatophores per mated female was decreased by increasing the dose to parental males.

The Percentage of $F_{1}$ progeny survived to adult stage was reduced at 50 Gy and the reduction increased by increasing the dose of irradiation. The average larval duration seemed to be about the control in the progeny of the $50 \mathrm{~Gy}$, while the average larval duration increased at 100 and 150 Gy compared to their control treatment. The average pupal duration seemed to be about the control in the progeny of the 50 Gy, while the average pupal duration at 100 and 150 Gy was clearly affected compared to the control treatment. The percentage of pupation seemed to be about normal at $50 \mathrm{~Gy}$, while it was reduced at 100 and 150 Gy, respectively. The percentage of adult emergence decreased with increased irradiation dose. The sex ratio among the progeny of irradiated males seemed to be skewed some what to male side especially at 100 and 150 Gy
\end{abstract}




\section{INTRODUCTION}

Insects belonging to order Lepidoptera are among the most harmful pests of food crops and stored products throughout the world. Currently, most of these species are widely controlled by applying chemical insecticides. This practice has induced insecticides resistance. In addition, the frequent use of chemicals often destroys both natural enemies that keep a variety of pests in check, pollinating insects in addition to other beneficial organisms. Nonchemical methods of controlling lepidopteran pests are being developed and widely used. These alternatives include many biological, ecological, genetic and cultural methods. Genetic control of lepidopteran pests includes the use of sterile insect technique. Generally, Lepidoptera requires very high doses of irradiation to induce sexual sterility. These high doses affect insect mating behavior and reproductive physiology. Inherited sterility is another form of genetic control in Lepidoptera using sub sterilizing doses to produce offspring which are patially or completely sterile. This technique offers significant advantages over classical sterile release methods.

The black cut worm, Agrotis ipsilon (Hufn.) is a serious pest of several important field and vegetable crops in Egypt, such as cotton, soybean, corn, potatoes, and tomatoes. Inherited sterility technique appeared to be promising in an integrated programme for the control of this insect pest and other serious ones. This technique could be used in controlling lepidopterous insects according to Proverbs (1962).

Many investigators studied this technique in many Lepidopterous pests i.e. Ashrafi and Roppel (1973), La Chance et al.(1973), Ibrahim (1981), Carpenter (1985), La Chance (1985), Anisimov et al. (1989), Sallam et al. (1996), and Sileem (2004).

The present study was conducted to investigate the effect of three low doses of gamma irradiation (50,100 and 150 Gy) on inherited sterility in the male and female of the black cut worm, Agrotis ipsilon.

\section{Insect Rearing Technique:}

\section{MATERIALS AND METHODS}

The culture of the tested insect, the black cutworm, Agrotis ipsilon (Hufn.) started by collecting healthy full grown larvae from an infested filed at Qualubia Governorate. These larvae were kept individually inside a glass tube with fresh castor oil plant leaves, Ricinus communis. Tubes were kept under laboratory conditions of $25^{\circ} \mathrm{C}$ and $60-70 \%$ R.H. Just before pupation, tubes were provided with saw dust as pupating media and daily checked to collect new formed pupae. Pupae were surface sterilized with formalin $10 \%$, sexed and kept on moistened saw dust . Full grown pupae of each sex were transferred to adult emergence cages provided with small glass vials, with a piece of cotton wool soaked with $10 \%$ sugar solution serving as adult's food. Chimney glass cages (used as mating cage) were lined and covered with toweling paper as oviposition site. The eggs were daily collected to start a new culture. Hatching occurred within 3-5 days inside glass jars provided with fresh castor oil plant leaves. Green leaves were renewed daily 
in the early three instars. Fourth and fifth instars larvae were kept in low numbers to avoid cannibalism together with fresh castor oil plant leaves which always occurred under the state of crowding (Ibrahim, 1981).

\section{Irradiation Technique:}

Full grown pupae of $A$. ipsilon (1- 2 days before emergence) were irradiated using a Gamma Cell (Cobalt 60 source) installed at the laboratory of Middle Eastern Regional Radioisotopes, Center for the Arab Countries, Cairo (Egypt). The irradiation dosimeter applied was $6.25 \mathrm{rad}^{*} / \mathrm{second}$ through the experimental work. Correction for decy was routinely run whenever needed at a half life of 5.3 years.

* Gray (Gy) $=100 \mathrm{rad}, \mathrm{k} \mathrm{rad}=1000 \mathrm{rad}$

\section{Experimental Procedures:}

\subsection{Parental generation:}

Newly emerged males and females resulting from the irradiated pupae were paired with their untreated opposite sex or with each other according to the following combinations:

1) Treated male (TM) $\times$ Untreated female (UF)

2) Treated female (TF) $\times$ Untreated male (UM)

3) Untreated male (UM) $\times$ Untreated female (UF)

Each single pair was introduced into $750 \mathrm{cc}$ cylindrical carton cage internally lined with white cloth as oviposition site. Cages were supplied with $10 \%$ sugar solution and covered with tissue paper fixed in place with a rubber band. Deposited eggs in all treatments were daily collected, counted, recorded and kept to determine the rate of egg hatch. In all mating treatments, experimental time lasted for 7 days. Then each female was dissected to determine number of spermatophores in the bursa copulatrix and the presence of sperms in spermathecae (Ibrahim, 1981).

\subsection{First generation:}

To continue the $F_{1}$ generation for male and female lines, newly hatched larvae from the irradiated full grown pupae at different sub sterilizing doses 50,100 and 150 Gy were kept in groups in glass jars provided with castor oil plant leaves. Four hundred larvae of the second instar of each treatment were transferred into plastic bowls furnished with a thin layer of saw dust to absorb the excess humidity. The rearing continued in the same way as the control until the larvae reached the last instar. Full grown larvae were then transferred to plastic bowls containing moistened saw dust for pupation.

Newly formed pupae were daily collected, sexed and each sex kept separately in plastic containers containing moistened saw dust and covered as usual with muslin cloth. The effects on development and reproductive biological aspects were also studied among the two successive generations $\left(P_{1}\right.$ and $\left.F_{1}\right)$ including that larval survival up to adult stage, development time and sex ratio were recorded.

3.3. Statistical analysis: Data were analyzed using Duncan's multiple range test. 


\section{RESULTS AND DISCUSSION}

\section{Full-grown male pupae:}

Full-grown male pupae were exposed to three doses of gamma irradiation 50, 100 and 150 Gy. The effect of these doses on some biological aspects of treated and untreated moths is given in Table (1). The results showed that, the number of eggs laid by untreated females mated with irradiated parental males did not significantly differ from untreated control at dose $50 \mathrm{~Gy}$, while the reduction in number of eggs was significant at 100 and 150 Gy.

Increasing the dose of irradiation applied to the parental male reduced the percentage of egg hatch. The reduction was significant at any tested dose level compared to the control treatment. The mating ability of irradiated $\mathrm{P}_{1}$ males was not clearly affected at any tested dose level. The average number of spermatophores per mated female decreased by increasing dose.

Table (1): Effect of gamma irradiation on the reproductive biology of Agrotis ipsilon (Hufn.) irradiated at full grown male pupae.

\begin{tabular}{|c|c|c|c|cc|}
\hline $\begin{array}{c}\text { Dose to } \mathbf{P}_{1} \\
\text { Male (Gy) }\end{array}$ & $\begin{array}{c}\% \\
\text { Mating }\end{array}$ & $\begin{array}{c}\text { Avg.no. of } \\
\text { spermato-phores }\end{array}$ & $\begin{array}{c}\text { Avg. no of } \\
\text { eggs } \pm \text { S.E }\end{array}$ & \multicolumn{2}{|c|}{$\begin{array}{c}\% \\
\text { Egg hatch }\end{array}$} \\
\hline 0 (control) & 100.0 & 2.0 & $1064 \pm 76.4 \mathrm{a}$ & 87.9 & $\mathrm{a}$ \\
50 & 100.0 & 1.7 & $977.9 \pm 55.9 \mathrm{ab}$ & 65.2 & $\mathrm{~b}$ \\
100 & 91.0 & 1.7 & $886.8 \pm 89.8 \quad \mathrm{~b}$ & 52.9 & $\mathrm{~b}$ \\
150 & 86.0 & 1.4 & $808 \pm 69.5 \quad \mathrm{~b}$ & 33 & $\mathrm{C}$ \\
\hline
\end{tabular}

2. Effect on the First Generation $\left(F_{1}\right)$ (males line):

Data in Table (2) show that the average number of eggs was not significantly different from untreated control at 50 Gy but it was reduced significantly at 100 and 150 Gy. While when untreated males were crossed with $F_{1}$ females the reduction in the number of laid eggs was only significant at 150 Gy.

Table (2): Effect of gamma irradiation on the first generation of Agrotis ipsilon (Hufn.) resulted from $\mathrm{P}_{1}$ adult previously irradiated at full-grown male pupae.

\begin{tabular}{|c|c|c|c|c|c|}
\hline $\begin{array}{c}\text { Dose to } P_{1} \\
\text { male } \\
(G y)\end{array}$ & $\begin{array}{l}\text { Mating combination } \\
\text { Male Female }\end{array}$ & $\begin{array}{c}\% \\
\text { Mating }\end{array}$ & $\begin{array}{l}\text { Avg. no. of } \\
\text { Spermato- } \\
\text { Phoes }\end{array}$ & $\begin{array}{c}\text { Avg. no. of eggs } \\
\pm \text { S.E. }\end{array}$ & $\begin{array}{l}\text { \%Egg } \\
\text { hatch }\end{array}$ \\
\hline 0 (control) & U & 100.0 & 1.9 & $1085 \pm 51.3 \mathrm{a}$ & 89.5 \\
\hline 50 & $\begin{array}{l}\mathrm{T} \\
\mathrm{U} \\
\end{array}$ & $\begin{array}{r}93.0 \\
100.0 \\
\end{array}$ & $\begin{array}{l}1.9 \\
1.5 \\
\end{array}$ & $\begin{array}{c}1071 \pm 97.7 \text { a } \\
1154.6 \pm 110\end{array}$ & $\begin{array}{l}59.2 \quad b \\
63.4 \quad b \\
\end{array}$ \\
\hline 100 & $\begin{array}{l}\mathrm{T} \\
\mathrm{U}\end{array}$ & $\begin{array}{l}100.0 \\
100.0\end{array}$ & $\begin{array}{l}1.4 \\
1.3 \\
\end{array}$ & $\begin{array}{c}776.8 \pm 85.6 b \\
1041 \pm 91\end{array}$ & $\begin{array}{l}36.9 \\
50.6\end{array}$ \\
\hline 150 & $\begin{array}{l}\mathrm{T} \\
\mathrm{U} \\
\end{array}$ & $\begin{array}{r}93.0 \\
100.0 \\
\end{array}$ & $\begin{array}{l}1.1 \\
1.2 \\
\end{array}$ & $\begin{array}{ll}610 \pm 89 & b \\
566.5 \pm 65 & b\end{array}$ & $\begin{array}{l}10.1 \quad \mathrm{c} \\
20.8 \quad \mathrm{c} \\
\end{array}$ \\
\hline
\end{tabular}


Results showed that, the percentage of egg hatch was reduced at all tested mating combination of $F_{1}$ in comparison to their untreated control. The reduction in egg hatch was more pronounced in mating combinations $(T M \pm$ $\mathrm{UF}, \mathrm{UM} \pm \mathrm{TF}$ ), at $150 \mathrm{~Gy}$ and (TM $\times \mathrm{UF}$ ) at $100 \mathrm{~Gy}$, in comparison to the control treatment. The irradiation did not clearly affect the percentage of mating at any tested mating combination, while the average number of spermatophores / mated female gradually decreased by increasing the dose.

Table (3) shows that when $P_{1}$ males were irradiated at 50,100 and 150 Gy and crossed with untreated females the percentage of $F_{1}$ progeny survived to adult stage was reduced to $70.0 \%$ at $50 \mathrm{~Gy}$, and the reduction increased to $66.0 \%$ at $100 \mathrm{~Gy}$, in comparison to the untreated control (81.0\%). The highest reduction was observed at 150 Gy treatments (56.0\%). The average larval duration seemed to be about the control in the progeny of the 50 Gy, while it increased to 29.0 and 31.5 days at 100 and 150Gy respectively compared to control (23.8 days). Also, the average of pupal duration took the same trend of larval duration.

The percentage of pupation seemed to be about normal at $50 \mathrm{~Gy}$, while it was reduced $(69.3 \%)$ at 100 and $(50 \%)$ at 150 Gy. Also, the same trend was observed in adult emergence where increasing the irradiation dose gradually reduced the adult emergence. The sex ratio among the progeny of irradiated males seemed to be skewed somewhat to male side especially at 100 and 150Gy.

Table (3): Effect of gamma irradiation on some biological aspects of imature stages resulted from $\mathbf{P}_{1}$ Agrotis ipsilon (Hufn.) adults previously irradiated as full grown male pupae.

\begin{tabular}{|c|c|c|c|cc|c|c|}
\hline $\begin{array}{c}\text { Dose to } \\
\mathbf{P}_{1} \\
\text { Male } \\
\text { (Gy) }\end{array}$ & $\begin{array}{c}\text { \% Larvae } \\
\text { surviving } \\
\text { to adults }\end{array}$ & $\begin{array}{c}\text { Larval } \\
\text { duran } \\
\text { (days) } \\
\mathbf{\pm S . E}\end{array}$ & $\begin{array}{c}\text { \% } \\
\text { Pupa } \\
\text {-tion }\end{array}$ & \multicolumn{2}{|c|}{$\begin{array}{c}\text { Pupal duration } \\
\text { (days) } \pm \text { S.E } \\
\text { Male }\end{array}$} & $\begin{array}{c}\text { Female } \\
\text { Emer-gence }\end{array}$ & $\begin{array}{c}\text { Sex ratio } \\
\text { Male:Female }\end{array}$ \\
\hline 0 & 81.0 & $23.8 \pm 0.28$ & 88.0 & $14.1 \pm 0.01$ & $13.8 \pm 0.76$ & 91.0 & $1.0: 1.0$ \\
50 & 70.0 & $24.0 \pm 0.09$ & 87.0 & $13.4 \pm 0.74$ & $13.5 \pm 0.24$ & 75.0 & $1.3: 1.0$ \\
100 & 66.0 & $29.0 \pm 1.6$ & 69.3 & $15.3 \pm 0.01$ & $14.8 \pm 0.76$ & 59.0 & $1.4: 1.0$ \\
150 & 56.0 & $31.5 \pm 0.21$ & 50.0 & $16.9 \pm 0.31$ & $15.0 \pm 0.29$ & 57.0 & $1.5: 1.0$ \\
\hline
\end{tabular}

\section{Irradiated as full-grown female pupae:}

Full-grown female pupae were exposed to three doses of gamma irradiation, 50, 100 and 150 (Gy). Table (4) shows that the average number of eggs per treated female when mated with untreated male was significantly reduced. Increasing the dose of radiation applied to the parental female gradually reduced the percentage of egg hatch. The reduction was significant at all tested doses level compared to the control .

There was a reduction in the percentage of mating at all tested mating combination. The average number of spermatophores / mated female was not clearly affected. 
EIShabrawy, H. A. et al.

Table (4): Effect of gamma irradiation on the reproductive biology of Agrotis ipsilon (Hufn.) irradiated as full grown female pupae.

\begin{tabular}{|c|c|c|c|c|}
\hline $\begin{array}{l}\text { Dose to } P_{1} \\
\text { female (Gy) }\end{array}$ & \begin{tabular}{|c|} 
Avg. no eggs \pm \\
S.E
\end{tabular} & $\begin{array}{c}\% \\
\text { Egg hatch }\end{array}$ & $\begin{array}{c}\% \\
\text { Mating }\end{array}$ & $\begin{array}{c}\text { Avg. no. of } \\
\text { spermato-phores }\end{array}$ \\
\hline 0 (control) & $1136 \pm 64 \quad a$ & 88.0 & 100.0 & 1.7 \\
\hline 50 & $896 \pm 86 \quad a b$ & 46.9 & 93.0 & 1.4 \\
\hline 100 & $720 \pm 110 \quad b$ & 24.8 & 93.0 & 1.5 \\
\hline 150 & $629.2 \pm 92 \quad b$ & 6.4 & 76.0 & 1.7 \\
\hline
\end{tabular}

4. Effect of gamma irradiation on the first generation (F1) (Females line):

Data in Table (5) show that, the number of eggs was significantly reduced at all tested doses in different mating combinations (TM $\times$ UF) at 50 Gy.

The percentage of egg hatch was significantly reduced at all tested mating combinations in comparison to control treatment. However, the difference in egg hatch was not significant among the mating combination UMxTF at 100 and 150 Gy. The percentage of mating was not clearly affected in mating combinations at 50 and 100 Gy but it was reduced at 150 Gy. The average number of spermatophores per mated female was reduced at100 and 150 Gy.

Table (5): Effect of gamma irradiation on the first generation of Argotic ipsilon (Hufn.) resulted from adults previously irradiated as full grown female pupae.

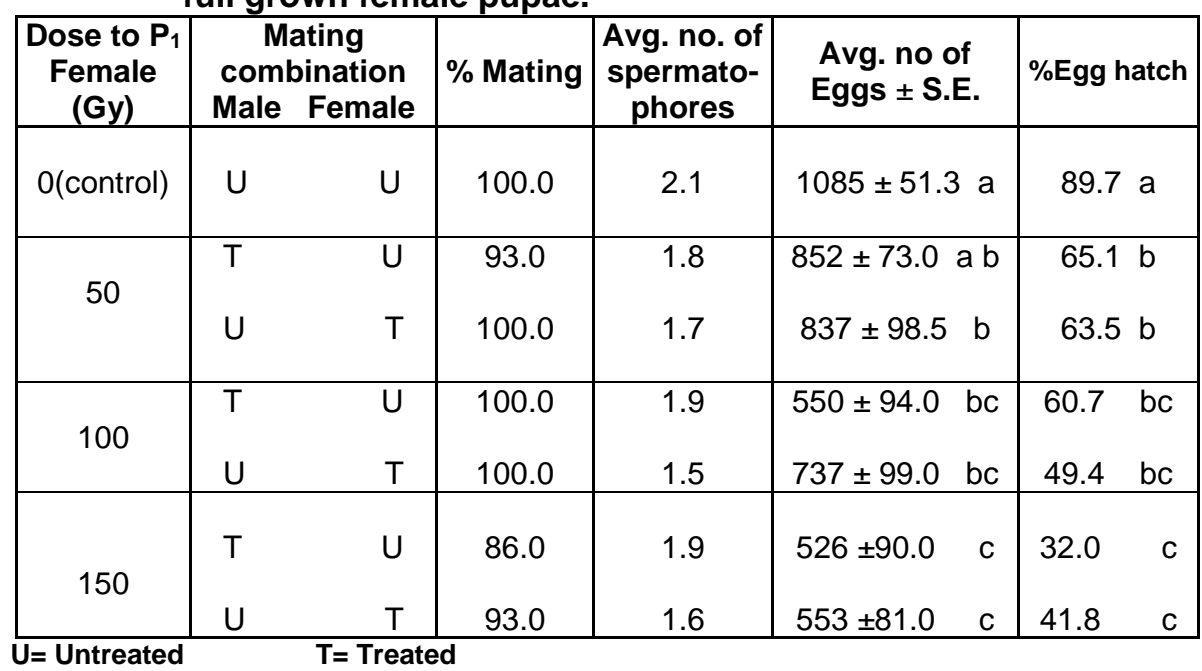


Table (6) shows the obtained data when $\mathrm{P}_{1}$ females were irradiated and crossed with untreated males. The percentage of $F_{1}$ larvae survived to adult stage was obviously reduced in comparison to the untreated control. The average of larval duration seemed to be about the control in the progeny at $50 \mathrm{~Gy}$, while the average was increased at 100 and $150 \mathrm{~Gy}$, in comparison to control. The percentage of pupation was slightly affected at 50 and $100 \mathrm{~Gy}$, while it was reduced at 150 Gy $(65.0 \%)$ in comparison to the control. The pupal duration seemed to be about normal at 50 and 100 Gy while it increased at 150 Gy. The adult emergence was reduced at 150 Gy but it was slightly reduced at 50 and 100 Gy. The sex ratio among the progeny of irradiated females seemed to be around control treatment.

Table (6): Effect of gamma irradiation on some biological aspects of Agrotis ipsilon Hufn.) immature stages resulted from $\mathbf{P}_{1}$ adults previously irradiated as full grown female upae.

\begin{tabular}{|c|c|c|c|c|c|c|c|c|}
\hline $\begin{array}{c}\text { Dose to } \\
\mathbf{P}_{1} \\
\text { Male } \\
\text { (Gy) } \\
\end{array}$ & $\begin{array}{c}\% \text { Larvae } \\
\text { surviving to } \\
\text { adults }\end{array}$ & $\begin{array}{c}\text { Larval } \\
\text { duration } \\
\text { (days) } \\
\pm \text { S.E } \\
\end{array}$ & $\begin{array}{c}\% \\
\text { Pupa } \\
\text { tion }\end{array}$ & \multicolumn{2}{|c|}{$\begin{array}{l}\text { Pupal duration } \\
\text { (days) } \pm \text { S.E }\end{array}$} & $\begin{array}{c}\% \\
\text { Emer- } \\
\text { ence }\end{array}$ & \multicolumn{2}{|c|}{$\begin{array}{c}\text { Sex ratio } \\
\text { Male : Female }\end{array}$} \\
\hline 0 & 92.0 & $21.3 \pm 0.32$ & 93.0 & $14.1 \pm 0.01$ & $13.8 \pm 0.76$ & 96.0 & 1.1 & $: 1.0$ \\
\hline 50 & 86.0 & $23.0 \pm 0.25$ & 87.0 & $13.3 \pm 0.08$ & $12.1 \pm 0.12$ & 89.0 & 1.2 & : 1.0 \\
\hline 100 & 78.0 & $27.5 \pm 0.09$ & 85.3 & $13.4 \pm 0.74$ & $12.9 \pm 0.23$ & 84.0 & 1.1 & $: 1.0$ \\
\hline 150 & 65.0 & $31.0 \pm 0.36$ & 65.0 & $16.9 \pm 0.31$ & $17.0 \pm 0.29$ & 76.0 & 1.2 & $: 1.0$ \\
\hline
\end{tabular}

The results indicated that, females are more sensitive to irradiation than males. Similar results were reported by authors working on other insects. La Chance et al (1973) on Pectinophora gossypiella, Loaharanu et al. (1975) on Spodoptera exigua, Carpenter (1985) on Heliothis zea; and Sallam et al. (1996) on Earias insulana.

Also,the results indicated that, a reduction in number of eggs laid per female was observed in $F_{1}$ generation among the two tested doses (100 and $150 \mathrm{~Gy}$ ) applied to $P_{1}$ males and females. Also, the reduction in the average number of eggs was significant at 100, 150, and 50 Gy $(U M \times T F)$ for $F_{1}$ female. While the reduction was significant at 150 Gy for $F_{1}$ males.

Also, the results indicate that the percentage of egg hatch of $F_{1}$ generation was gradually reduced by increasing the dose to the full grown male and female pupae. This reduction was significant at 50,100 and $150 \mathrm{~Gy}$ in all mating combinations in comparison to the untreated control. The reduction in egg hatch was greater in $F_{1}$ male than $F_{1}$ female in all mating combination. These results indicate that the percentage of egg hatch of $F_{1}$ male was more reduced than $\mathrm{P}_{1}$ males.

The low egg hatch in $F_{1}$ progeny can be attributed to 1 or more of the following 5 reasons: (1) poor ability to mate; (2) failure to produce as many spermatophores as normal males; (3) transfer spermatophores that contain little or no sperm; (4) abnormal sperm structure, which fails to fertilize the 
eggs (Ashrafi and Roppel 1973); or (5) inheritance of special chromosome rearrangements (La Chance 1985, Anisimov et al. 1989).

The above results lead to a conclusion that sterility could be inherited by irradiation of full grown male pupae more than irradiated full grown female pupae. The results confirmed the fact that $F_{1}$ males were more sterile than their irradiated parents. These results agree with those obtained by Proverbs (1962) on Carpocapsa pomonella and Sileem (2004) on Agrotis ipsilon.

\section{REFERENCES}

Anisimov, A.I.; N.V. Lazurkina and A.N. Shvedov (1989). Influnce of radiationinduced genetic damage on the suppressive effect of inherited sterility in the codling moth (Lepidoptera: Tortricidae). Ann. Entomol. Soc. Am. 82: 769-777.

Ashrafi, S.H. and R.M. Roppel (1973). Radiation induced partial sterility related to structurally abnormal sperm of Plodia interpunctella. Ann. Entomol. Soc. Am. 66: 1309-1314.

Carpenter, J.E. (1985). Radio-induced inherited sterility in Heliothis zea (Boddie.). Ph. D. Thesis. Florida Univ., Gainesville (U.S.A.).cited from Allam El-Din (2001).

Ibrahim, S.M. (1981). Studies on the effects of gamma irradiation on the black cut worm, Agrotis ipsilon (Hufn.) M. Sc. Thesis, Fac. of Agric., Cairo Univ

La Chance, L.E. (1985). Genetic methods for the control of Lepidoptera species: status and potential. US. Dep. Agric. Res. Serv. ARS. 28.

La Chance, L.E.; R.A. Bell and R.D. Richard (1973). Effect of low doses of gamma irradiation on reproduction of male pink bollworm and their $F_{1}$ progeny. Environ. Entomol., 2: 653-658.

Loaharnu, S.; S. Chirovatanopeng; S. Sutanta-Wong and P.Kaoehnong (1975). Mating competitiveness of the radiosterilized male army worm, Spodoptera exigua ( $\mathrm{Hb}$.) and the male mosquito Aedes aegypti in field cages. Sterility Principlles for Insect Control (IAEA. SIT/PUB. 37: 317323).

Proverbs, M.D. (1962). Progress on the use of induced sexual sterility for the control of codling moth, Carpocapsa pomonella. Proc. Entomol. Soc. Ontario, 29: 5-11.

Sallam, H.A.; S.A. El-Dessouki ; A.A. El-Saedy and H.F. Mohamed (1996). Effect of gamma radiation on reproduction and mating competitiveness in the spiny boll worm, Earias insulana (Boisd.). $6^{\text {th }}$ Conf. of Nucl. Sci. and Appl. Cairo, 15-20 March, 1996

Sileem, Thanaa, M. (2004). Effect of gamma radiation and some plant extracts on the black cut worm Agrotis ipsilon (Hufn.). M. Sc. Thesis, Fac. Agric. Moshtohor, zagazig, Univ.: 129 pp. 
تأثير أثـعة جامـا على بعض النـواحي البيولوجيـة في الدودة القارضـة السـوداء Agrotis ipsilon

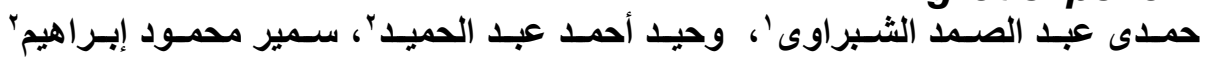

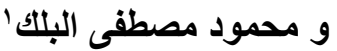

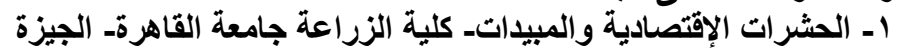

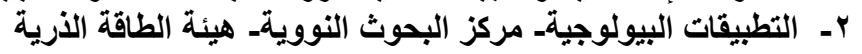

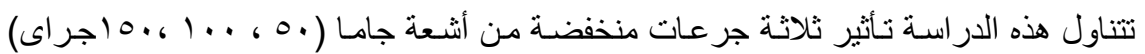

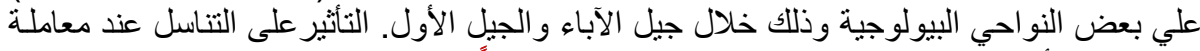

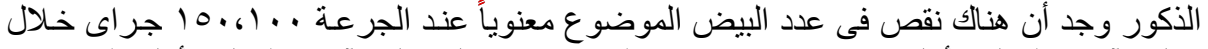

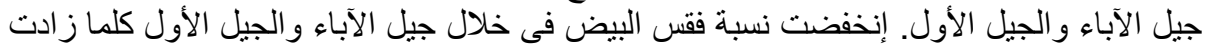

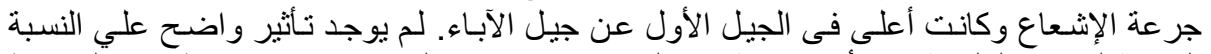

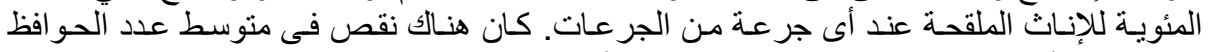

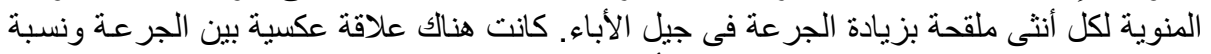

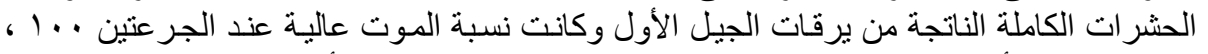

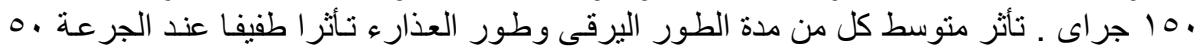

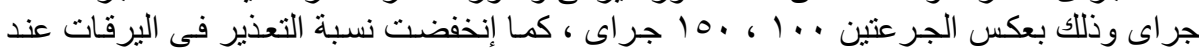

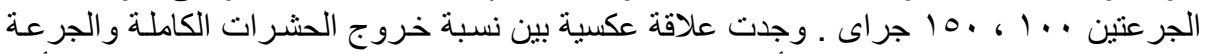

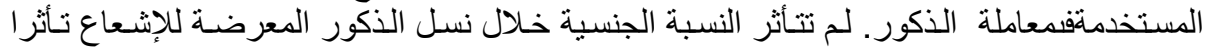
و اضحا وذلك عند جميع الجرعات المستخدمة وذللك بالمقارنة بالمعاملة القياسية .

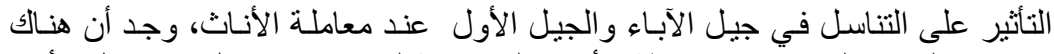

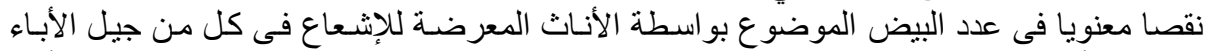

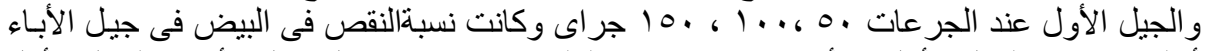

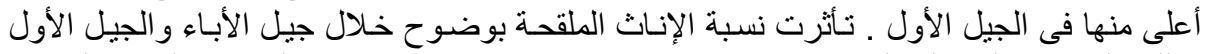

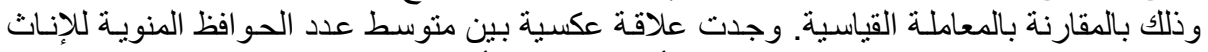

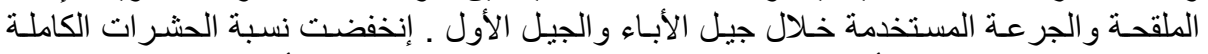

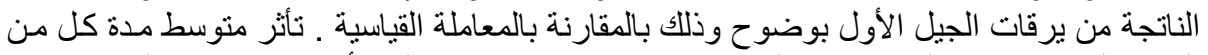

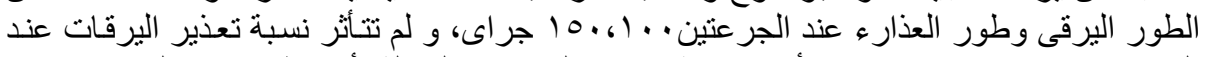

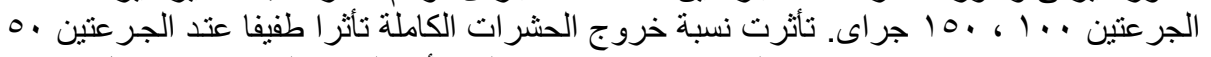

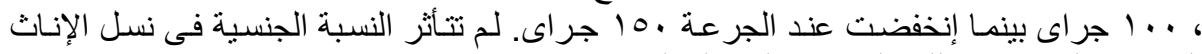
المعرضة للإثعاع وذللك بالمقارنة بالمعاملة القياسية. 